\title{
Mixed Juice Consumption During Labor to the Mother's Blood Lactate Levels
}

\author{
Rezah Andriani, ${ }^{1}$ Mieke Hemiawati Satari, ${ }^{2}$ Yudi Mulyana Hidayat, ${ }^{3}$ Farid Husin, ${ }^{4}$ \\ Gaga Irawan Nugraha, ${ }^{4}$ Hadi Susiarno, ${ }^{3}$ Wisnu Cahyadi ${ }^{5}$ \\ ${ }^{1}$ Midwifery Master Study Program, Faculty of Medicine, Universitas Padjadjaran, Bandung, Indonesia, \\ ${ }^{2}$ Department of Oral Biology, Faculty of Dentistry, Universitas Padjadjaran, Bandung, Indonesia, \\ ${ }^{3}$ Department of Obstetrics and Gynecology, ${ }^{4}$ Department of Public Health, Faculty of Medicine, \\ Universitas Padjadjaran, Bandung, Indonesia, 5 Department of Food Technology, \\ Faculty of Engineering, Universitas Pasundan, Bandung, Indonesia
}

\begin{abstract}
Maternal nutritional aim to prevent fatigue marked by lactate accumulation. Mix juice is made for the needs of the mother's energy quickly and reduces the accumulation of lactate. The objective of this study was to find out the influence of mix juice during labor to the mother's blood lactate levels. This study used a randomized controlled trial pretest-posttest group design. This research was carried out at the Pelayanan Obstetri Neonatal Emergency Dasar/ PONED (Basic Emergency Obstetric and Neonatal Care/BEONC) Puskesmas (Public Health Center) Garuda, Puter, Pagarsih, Padasuka, and Ibrahim Aji in Bandung city in March-April 2017. Simple random sampling used with the number of samples were 60 mothers in treatment and control group. The treatment group received mix juice during labor, while the control group consumed regular food. The result was analyzed using comparative-numerical categorical analysis test, and the mean difference was analyzed using unpaired t test. The results showed the average increased in blood lactate levels in the treatment group $(1.9 \mathrm{mmol} / \mathrm{L})$ was lower than in the control group (4.0 $\mathrm{mmol} / \mathrm{L}$ ). Statistically, there was a significant difference in elevated blood lactate levels after intervention between the treatment and control group. Mothers who did not receive the mixed juice in labor have a risk of elevated blood lactate levels four times higher than the mothers who received the mixed juice. Conclusion, giving mix juice to the labor process affects the prevention of maternal blood lactate levels.
\end{abstract}

Key words: Labor, lactate level, mix juice

\section{Konsumsi Minuman Mix Juice pada Persalinan untuk Kadar Laktat Darah Ibu}

\begin{abstract}
Abstrak
Kebutuhan nutrisi ibu bersalin bertujuan mencegah kelelahan yang ditandai dengan akumulasi laktat. Mix juice dibuat untuk memenuhi kebutuhan energi ibu bersalin secara cepat dan mengurangi penumpukan laktat. Penelitian ini bertujuan menganalisis pengaruh pemberian mix juice terhadap kadar laktat darah ibu. Penelitian ini menggunakan desain randomized controlled trial pretest-posttest group. Penelitian dilaksanakan di Puskesmas Pelayanan Obstetri Neonatal Emergensi Dasar (PONED) Garuda, Puter, Pagarsih, Padasuka, dan Ibrahim Aji di Kota Bandung pada Maret-April 2017. Populasi penelitian adalah semua ibu yang akan melahirkan di Kota Bandung. Penarikan sampel dilakukan secara acak yang berjumlah 60 orang pada kelompok perlakuan dan kontrol. Kelompok perlakuan mendapatkan mix juice selama persalinan, sedangkan kelompok kontrol dibebaskan untuk makan dan minum. Hasil dianalisis menggunakan uji analisis komparatif kategorik numerik dan perbedaan rerata dianalisis menggunakan uji t tidak berpasangan. Hasil penelitian didapatkan rerata kenaikan kadar laktat darah pada kelompok perlakuan (1,9 mmol/L) lebih rendah dibanding dengan kelompok kontrol (4,0 mmol/L). Secara statistik terdapat perbedaan bermakna dalam kenaikan kadar laktat darah setelah intervensi antara kelompok perlakuan dan kontrol. Ibu yang tidak mendapatkan mix juice pada persalinan memiliki risiko kenaikan kadar laktat darah 4 kali lebih tinggi dibanding dengan ibu yang mendapatkan mix juice pada persalinan. Simpulan, pemberian mix juice pada proses persalinan berpengaruh terhadap pencegahan peningkatan kadar laktat darah ibu.
\end{abstract}

Kata kunci: Kadar laktat, mix juice, persalinan

Received: 30 August 2017; Revised: 10 December 2018; Accepted: 12 December 2018; Published: 31 December 2018

Correspondence: Rezah Andriani. Midwifery Master Study Program, Faculty of Medicine, Universitas Padjadjaran. Jln. Prof. Eyckman No.38 Bandung 40161, West Java, Indonesia. Mobile: +6281363479924. E-mail: apriyandimelly@gmail.com 


\section{Introduction}

Labor complications can increase mortality and morbidity for mother and baby. Childbirth is often followed by fatigue both physiologically and psychologically and has adverse effects in the delivery process, one of which is prolonged labor. Prolonged labor increases maternal and neonatal mortality and morbidity. ${ }^{1}$ Labor fatigue is influenced by various factors that occur naturally, such as changes in body metabolism, changes in energy needs, activity patterns, sleep patterns, social status, lifestyle, psychological conditions, and environmental factors. A result of energy metabolism explained one of the causes of physiological fatigue in labor, in which there is an accumulation of lactate in muscle activity caused by lack of oxygen and a reduction in muscle glycogen levels. Tzeng et al.' ${ }^{2}$ study state that there is a relationship between lactate levels and the level of fatigue in labor. Increased fatigue during labor associated high blood lactate levels. Lactate levels are an indicator of fatigue.

High-intensity physical activity such as labor can cause an increase in lactic acid levels in muscles and blood. Increased levels of lactate can cause a decrease in $\mathrm{pH}$ which will inhibit the action of enzymes or chemical reactions in cells, especially in the muscles themselves, thus affecting the ability of the maximum muscle fibers to work, decreased physical performance and caused fatigue. There is an increase in energy requirements in labor so that sufficient energy needed during labor. ${ }^{3,4}$ Lack of nutritional intake during labor can have a detrimental effect on the mother, baby, and the progress of labor. ${ }^{5,6}$

During labor, there is an increased oxygen demand along with the increase uterine contractions when oxygen is not sufficiently available there is anaerobic metabolism, and lactate produced as a by-product. The concentration of lactic acid increases in the first phase of the active phase and improvements in the second stage as a result of straining. ${ }^{4}$ Lactic acid insufficient oxygen can be converted back to pyruvic acid and then undergo an oxidative system to produce energy. This process is called the Cori cycle which can only run if there is adenosine triphosphate (ATP) as the fuel for the procedure. Lactic acid buildup occurs when the amount of lactic acid produced is greater than the amount of lactic acid metabolized by the body or in other words the rate of lactic acid formation is higher than the speed of decomposition (recovery). 7,8

Based on preliminary studies that have been carried out on 30 mothers giving birth to nutrition fulfillment patterns during the delivery process. It concluded that usually the mothers still consume food at the latent phase, entering the first phase of the active phase and when the second stage most mothers refuse to waste food due to taste more frequent pain. The average number of calories they consume during labor is only $30 \mathrm{kcal} /$ hour.

Energy requirements in labor are assumed to be similar to energy requirements for moderate aerobic exercise. From several existing research journals, the energy needs of maternity women estimated at 50-100 kcal/hour..$^{9,10}$

Maternity mothers still need all the nutrients that needed in general, but in labor, there are physiological changes such as the occurrence of inhibition of gastric emptying and decreased gastrointestinal motility so that the absorption of nutrients lasts longer. Besides, there are also psychological changes during labor such as anxiety facing childbirth so that the mother does not have the desire to eat and drink, and this also occurs due to the pain caused by contractions that are increasingly frequent. Nutritional needs of the mother fulfilled by providing an intake in the form of a liquid that easily digested and quickly absorbed into energy, delicious (does not cause nausea), practical, and suitable with the condition of the mother who will give birth. ${ }^{11}$ One of them is by providing drinks in the form of mix juice, and ingredients used to make mix juice drinks such as honey, dates, dried red beans, oranges, mangoes, and guava. Mix juice is a mixture of several raw materials that have a complete nutritional composition to improve the taste and density of nutritional value so that all nutrients from various ingredients mixed. ${ }^{5,12}$

The main dietary content of these ingredients (such as honey, dates, and fruits) are mostly simple carbohydrates such as fructose and glucose are ketose and aldose sugars, each of which has a different chemical structure and metabolic pattern. Both become monosaccharides with a tendency to experience rapid burning. Glucose rapidly metabolized and absorbed into the circulatory system to provide energy, but it also burns quickly, while absorption of fructose travels slower (fructose is released slowly into the bloodstream to produce sustained energy, increase and maintain homeostasis), fructose 
continue to sustain individuals with the power generated. ${ }^{13,14}$

Besides containing high carbohydrates, mix juice is also rich in protein and fat which can also be used as an energy source even though the absorption process is not as fast as carbohydrates. Mix juice is also rich in vitamins and minerals, especially vitamin B contained in fruits as ingredients for making mix juice, which functions to accelerate the metabolism of energy formation. Mix juice can provide a source of energy quickly so that it is easily absorbed by the body to produce energy, saves glycogen use and accelerates the return of glycogen used. Thus lactate levels that accumulate will decrease faster. The purpose of this study was to analyze the effect of giving mixed juice drinks during labor to prevent the increase of maternal blood lactate levels. ${ }^{13}$

\section{Methods}

This study was a randomized controlled trial (RCT) pretest-posttest group design, which was conducted on 60 women with gravida 4 who would give birth at the basic emergency obstetric and neonatal care/BEONC (pelayanan obstetri neonatal emergensi dasar/PONED) puskesmas (public health center) in Bandung city (30 treatment groups and 30 control groups). Sampling in this study was conducted randomly by block randomization with block permutation. This research was carried out at the PONED Public Health Center Garuda, Puter, Pagarsih, Padasuka, and Ibrahim Aji in March-April 2017.

Inclusion criteria were parturients aged 20-35 years, pregnant women with gravida $<4$ came with the latent phase, the results of obstetric examination of term infants, single, and healthy, normal body mass index (BMI) before pregnancy. Exclusion criteria have specific food allergies, experiencing complications during pregnancy and childbirth, having a history of gastritis, and a history of metabolic disorders. The requirements for dropping out were the total consumption of mix juice during labor less than the minimum dose of $100 \mathrm{kcal} /$ hour, delivery with action, the presence of fetal distress during labor, prolonged labor, and the presence of his disorder (hypertonus).

The treatment group received mix juice during the first stage until the third stage of labor, while the control group was free to eat and drink during labor. Blood lactate levels were measured by looking at maternal capillary blood lactate levels using the Accutrend Plus brand lactate levels. The result of the test was analyzed using comparativenumerical categorical analysis test. The mean difference was analyzed using unpaired $t$ test.

Mix juice formulation was carried out in the laboratory to get standard mixed juice drinks, conducted several trials (trial and error) so that there were three suitable formulations, then organoleptic tests were carried out to determine the best formulation. The wording is a mixture of ingredients such as dates, honey, red beans, oranges, and red guava/mango.

This research has received a permit from the Health Research Ethics Committee of Faculty of Medicine, Universitas Padjadjaran Bandung by ethics approval letter number: 309/UN6.C.10/ $\mathrm{PN} / 2017$.

\section{Results}

The test on the quality of mix juice drinks was carried out in the Food Analysis Laboratory, Department of Food Technology, Faculty of Engineering, Universitas Pasundan. The quality test aims to assess the content of protein, fat, carbohydrates, water content, and ash content in

Table 1 Mix Juice Drinks Quality Analysis

\begin{tabular}{|c|c|c|c|}
\hline Characteristics & $\begin{array}{c}\text { Red Guava Mix Juice } \\
\text { (per } 100 \mathrm{~mL})\end{array}$ & $\begin{array}{l}\text { Manggo Mix Juice } \\
\text { (per 100 mL) }\end{array}$ & $\begin{array}{c}\text { Quality Requirements } \\
\text { (per } 100 \mathrm{~mL})\end{array}$ \\
\hline Water content $(\%, w / w)$ & $76.6537 \%$ & $77.2111 \%$ & - \\
\hline Ash content $(\%, \mathrm{w} / \mathrm{w})$ & $1.273 \%$ or $0.0132 \mathrm{~g}$ & $1.2331 \%$ or $0.0127 \mathrm{~g}$ & Max. $1.1 \mathrm{~g}$ \\
\hline Carbohydrate (\%, w/w) & $20.872 \%$ or $83.490 \mathrm{kcal}$ & $19.967 \%$ or $83.063 \mathrm{kcal}$ & Max. $11.4 \mathrm{~g}$ or $45.6 \mathrm{kcal}$ \\
\hline Protein $(\%, w / w)$ & $1.862 \%$ or $7.449 \mathrm{kcal}$ & $1.723 \%$ or $7.171 \mathrm{kcal}$ & $3.2-4.4 \mathrm{~g}$ or $12.8-17.6 \mathrm{kcal}$ \\
\hline Fat $(\%, w / w)$ & $1.7923 \%$ or $16.131 \mathrm{kcal}$ & $1.695 \%$ or $15.866 \mathrm{kcal}$ & Min. $0.6 \mathrm{~g}$ or $5.4 \mathrm{kcal}$ \\
\hline Calories/energy (kcal) & $107.07 \mathrm{kcal}$ & $105,01 \mathrm{kcal}$ & Min. 56 kcal \\
\hline
\end{tabular}


Table 2 Characteristics of Research Subjects

\begin{tabular}{|c|c|c|c|}
\hline \multirow{2}{*}{ Characteristics } & \multicolumn{2}{|c|}{ Groups } & \multirow{2}{*}{ p Value } \\
\hline & Treatment $(n=30)$ & Control $(n=30)$ & \\
\hline Age (years) & & & $0.149^{*}$ \\
\hline $20-24$ & 11 & 9 & \\
\hline $25-29$ & 11 & 6 & \\
\hline $30-35$ & 8 & 15 & \\
\hline $\mathrm{x}(\mathrm{SD})$ & $26.3(4.5)$ & $28.3(5.5)$ & \\
\hline Range & $20-35$ & $20-35$ & \\
\hline Work & & & $0.573^{*}$ \\
\hline Yes & 8 & 10 & \\
\hline No & 22 & 20 & \\
\hline Body mass index $\left(\mathrm{kg} / \mathrm{m}^{2}\right)$ & & & $0.407^{* *}$ \\
\hline $\mathrm{x}(\mathrm{SD})$ & $21.2(1.8)$ & $21.6(1.8)$ & \\
\hline Median & 21.2 & 21.5 & \\
\hline Range & $18.5-24.9$ & $18.6-24.9$ & \\
\hline Anxiety level & & & $0.453^{*}$ \\
\hline There is no anxiety & 23 & 26 & \\
\hline Mild anxiety & 6 & 4 & \\
\hline Medium & 1 & o & \\
\hline Gravida & & & $0.602^{*}$ \\
\hline Primigravida & 14 & 12 & \\
\hline Multigravida & 16 & 18 & \\
\hline Duration of labor (minute) & & & $0.066^{* *}$ \\
\hline $\mathrm{x}(\mathrm{SD})$ & 271.5 (81.9) & $321.5(121)$ & \\
\hline Median & 272.5 & 326.5 & \\
\hline Range & $125-473$ & $131-660$ & \\
\hline
\end{tabular}

"Chi-square test, ${ }^{* *}$ independent $\mathrm{t}$ test

labor drinks. Analysis of protein content used the Kjeldahl method, analysis of fat with the Soxhlet method, carbohydrates using the Luff Schoorl method, and determination of water content and ash content using the gravimetric method. Resolution of storability is to test the microbial contamination method with total plate count (TPC) and E. coli.

Table 3 Analysis of Differences in Blood Lactate Levels Before and After Interventions

\begin{tabular}{|c|c|c|c|}
\hline \multirow{2}{*}{ Blood Lactate Levels } & \multicolumn{2}{|c|}{ Groups } & \multirow{2}{*}{ p Value } \\
\hline & Treatment $(n=30)$ & Control $(n=30)$ & \\
\hline Before intervention (mmol/L) & & & $0.296^{*}$ \\
\hline $\mathrm{x}(\mathrm{SD})$ & $2.6(0.8)$ & $2.4(0.7)$ & \\
\hline Median & 2.4 & 2.4 & \\
\hline Range & $1.3-4.5$ & $1.2-4.1$ & \\
\hline After intervention (mmol/L) & & & $<0.001^{* *}$ \\
\hline $\mathrm{x}(\mathrm{SD})$ & $4.6(1.1)$ & $6.5(2.1)$ & \\
\hline Median & 4.6 & 5.9 & \\
\hline Range & $2.9-6.8$ & $3.5^{-10.5}$ & \\
\hline Comparison before vs after & & & \\
\hline $\mathrm{p}$ value & $<0.001^{*}$ & $<0.001^{* * * *}$ & \\
\hline Increase in blood lactate level (mmol/L) & & & $<0.001^{* *}$ \\
\hline $\mathrm{x}(\mathrm{SD})$ & $1.9(0.8)$ & $4.0(1.8)$ & \\
\hline Median & 1.9 & 3.4 & \\
\hline Range & $0.4-4.3$ & $1.8-9.3$ & \\
\hline
\end{tabular}

"Independent t test, " Mann-Whitney test, ${ }^{* * *}$ Wilcoxon test 
Table 4 Analysis of the Effect of Mix Juice on the Process of Childbirth Against Prevention of Increase in Mother's Blood Lactate Level

\begin{tabular}{lcccc}
\hline \multirow{2}{*}{ Groups } & \multicolumn{2}{c}{ Increase in Blood Lactate Level } & \multirow{2}{*}{ p Value $^{*}$} & \multirow{2}{*}{ RR (95\% CI) } \\
\cline { 2 - 3 } & $>\mathbf{2 . 3 5}$ & $\mathbf{5 2 . 3 5}$ & & \\
\hline Control & 24 & 6 & $<0.001$ & $4.0(1.9-8.3)$ \\
Treatment & 6 & 24 & & \\
\hline
\end{tabular}

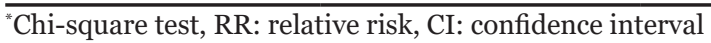

Table 1 shows that most of the values mix juice have standard requirements for quality drinks for pregnant women based on Indonesian National Standard (Standar Nasional Indonesia/SNI) 017148-2005, with several ingredients adjusted to the needs of the mothers.

Table 2 shows that there were no statistically significant differences between the two study groups regarding age, occupation, maternal BMI, anxiety level, gravida, and duration of labor ( $p>0.05)$. Based on the homogeneity of the characteristics of the two research groups, the two research groups are suitable for comparison.

Table 3 shows that at the beginning of the study mean blood lactate level of the treatment group was higher $(2.6 \mathrm{mmol} / \mathrm{L})$ than the control group $(2.4 \mathrm{mmol} / \mathrm{L})$ while at the end of the study the mean blood lactate levels of the treatment group was lower $(4.6 \mathrm{mmol} / \mathrm{L})$ than the control group $(6.5 \mathrm{mmol} / \mathrm{L})$. In the treatment and control groups, there were significant differences between blood lactate levels before and after the intervention $\mathrm{p}<0.05$. Table 3 also shows that there were no significant differences in blood lactate levels before intervention between the treatment and control groups $(p>0.05)$. However, there were significant differences in blood lactate levels after the intervention between the treatment and control groups $\mathrm{p}<0.05$.

Table 3 shows the average difference in blood lactate levels in the treatment group $(1.9 \mathrm{mmol} / \mathrm{L})$ lower than in the control group $(4.0 \mathrm{mmol} / \mathrm{L})$. Statistically, there was a significant difference in the difference between blood lactate levels before and after the intervention between the treatment and control groups $\mathrm{p}<0.05$.

Table 4 shows that in the control group the study subjects who experienced an increase in blood lactate levels $>2.35$ (80\%) were more than in the treatment group (20\%). While the study subjects who experienced an increase in blood lactate levels $\leq 2.35$ more in the treatment group $(80 \%)$ than in the control group (20\%) so that mothers who did not get mix juice during labor had a risk of increasing high blood lactate levels (>2.35) by 4 times compared to mothers who received mix juice during labor. In this study, the number need to treat (NNT) values were 1.67 rounded to 2. The NNT value means that every two research subjects received mix juice an additional one research subject experienced prevention of increased blood lactate levels.

\section{Discussion}

The development of drinks for maternity mothers is made to meet nutritional needs in the form of fluids contain nutrients that are high calories, high carbohydrates, and enough vitamins, minerals, and water. ${ }^{6}$ Adequate energy requirements are the amount of food energy needed to balance total energy expenditure. Every individual needs substantial macronutrient intake to carry out physical activities, especially in labor. The body can break down carbohydrates, fats, and proteins as energy during physical activity. Although there is much potential energy stored in the body as fat, where fat can be broken down for fuel during intense exercise. Likewise, there is much protein in shape, but protein damage as energy is inefficient and supplies only a small portion of energy needs during exercise. Carbohydrates are the primary fuel needed during strenuous activity such as childbirth because these molecules can be broken down quickly as energy. The content of carbohydrates from ingredients that make mix juice drinks such as dates, honey, red beans, mangoes, oranges, and red guava is mostly glucose, sucrose, and fructose which are simple carbohydrates that can be used as a source of energy quickly. ${ }^{13,14}$

When food or drink chewed, it mixed with saliva, which consists of the enzyme ptyalin (an $\alpha$-amylase) secreted by the parotid gland. This enzyme is useful for breaking down starch into disaccharides and disaccharides 
into monosaccharides. The final product of carbohydrate digestion is monosaccharide. The small intestine absorbed monosaccharides and released into the bloodstream. Fructose, sucrose, and galactose must be metabolized to glucose by the liver. When excess energy in the form of carbohydrates, it will be stored in the skeletal muscle and the liver as glycogen with the help of the insulin hormone and will automatically maintain blood sugar balance. When the glycogen reserves are sufficient, excess glucose is oxidized and stored as fat. It is also important to remember that contraction of muscle fibers during strenuous exercise is very dependent on the availability of carbohydrates as energy because of their ability to use fat as limited energy. ${ }^{14,15}$

Carbohydrates circulated in the blood as glucose and stored in the muscles and the liver as glycogen. The process of glycogen formation in brief, namely the first stage is the formation of glucose-6-phosphate from glucose, with the help of glucokinase enzyme and get additional energy from ATP and phosphate. Furthermore, glucose-6-phosphate with glucoamylase enzyme becomes glucose-1-phosphate. Then, glucose1-phosphate reacts with uridine triphosphate (UTP) catalyzed by uridyl transferase to produce uridine diphosphate glucose (UDP-glucose) and pyrophosphate (PPi). The last stage occurs condensation between UDP-glucose and number one glucose in the primary glycogen chain produce a new glycogen chain with one additional unit of glucose. ${ }^{16}$

During physical activity such as labor, the breakdown of glycogen triggered by hormones such as adrenaline (or epinephrine). Muscle glycogen used as a fast source of energy in muscle contraction. The liver releases glucose into the blood to help meet energy needs during exercise, which moves in the active muscle where used. Continuous training will gradually drain glycogen levels in the muscles and liver. Carbohydrate intake can delay the onset of fatigue and increase prolonged exercise performance like labor, this is done to maintain high levels of carbohydrate oxidation or in other words, keep energy fulfillment through the pathway oxidative. ${ }^{17,18}$

Mix juice drinks as a source of instant energy (additional energy from outside the body) that is easily absorbed by the body serves to maintain glucose levels and conserve glycogen use so that the body does not need to break down other energy sources, and accelerate the return of glycogen that used so that the accumulated lactate levels reduced faster.,19 Lactic acid buildup occurs when the amount of lactic acid produced is greater than the amount of lactic acid metabolized by the body or in other words the speed of lactic acid formation is higher than the rate of decomposition (recovery). ${ }^{18}$ Lactic acid in conditions of sufficient oxygen can produce energy known as the Cori cycle. This process will only run optimally in the resting phase because oxygen from normal breathing is channeled maximally throughout the body and there is an opportunity to take simple carbohydrates that can be absorbed quickly in the digestive system. ${ }^{18,19}$ This is similar with a study which mother was given mix juice for the first stage until the third stage during labor. The mixed juice consumed when the mother is not experiencing contractions so that the mother has the opportunity to get the maximum oxygen and get carbohydrate intake. It is to prevent lactate buildup caused by the occurrence of decomposition of lactate through the Cori cycle which has run optimally.

In the control group, mothers allowed the freedom to consumed regular food during childbirth. The researchers were unable to control the number of calories that had to be spent by mothers because each mother had different desires in consuming food and drinks. Most of the mothers did not have the desire to eat foods such as rice and side dishes that had been provided by the health center due to the pain caused by increasingly frequent contractions, so that the average calorie of food consumed in the control group in this study ( $45.87 \mathrm{kcal} / \mathrm{hour}$ ) smaller than the intervention group (123.83 kcal/ hour). Causes the intake of nutrients obtained by the control group so that the body breaks down other energy sources.

It is also consistent with research Khanna and $\mathrm{Manna}^{13}$ about the effect of electrolyte drinks on blood lactate levels during exercise and recovery, blood lactate levels recorded during breaks at intervals every 10 minutes during exercise and recovery. Although most of the value is not significant, it was significantly lower $(p<0.01)$ values were recorded after 70 minutes of exercise (without supplementation $3.4 \pm 0.6 \mathrm{mmol} / \mathrm{L}$ compared with $2.1 \pm 0.4 \mathrm{mmol} / \mathrm{L}$ with supplementation). However, no significant changes recorded for lactate levels at peak training (without supplementation of $3.7 \pm 1.2 \mathrm{mmol} / \mathrm{L}$ with supplementation of $3.2 \pm 1.0 \mathrm{mmol} / \mathrm{L}$ ). At the 
time of recovery of blood, lactate levels different significantly $\quad(\mathrm{p}<0.05) \quad$ (no supplementation $2.5 \pm 0.9 \mathrm{mmol} / \mathrm{L}$; with supplementation of $1.5 \pm 0.4 \mathrm{mmol} / \mathrm{L})$. From the study described this could occur due to consumption of carbohydrates can prevent a decrease in blood glucose and maintain oxidation of carbohydrates or for efficient use of muscle glycogen early.

\section{Conclusion}

Conclusions from this study there is the effect of giving mixed juice in the labor process to prevent the increase in maternal blood lactate levels.

\section{Conflict of Interest}

All authors state there was no conflict of interest.

\section{References}

1. Fitriani, Mose JC, Herman H. Difference duration of labor at BC-MK15 birth chair with conventional bed in multiparous. GMHC. 2018;6(2):105-12.

2. Tzeng YL, Chao YMY, Kuo SY, Teng YK. Childbirth-related fatigue trajectories during labour. J Adv Nurs. 2008;63(3):240-9.

3. Purnomo NT. Pengaruh circulo massage dan swedia massage terhadap penurunan kadar asam laktat darah pada latihan anaerob. JPES. 2013;2(1):181-5.

4. Scheepers HC, de Jong PA, Essed GG, Kanhai HH. Fetal and maternal energy metabolism during labor in relation to the available caloric substrate. J Perinat Med. 2001;29(6):45764.

5. Maharaj D. Eating and drinking in labor: should it be allowed? Eur J Obstet Gynecol Reprod Biol. 2009;146(1):3-7.

6. The Royal College of Midwives Trust. Evidence based guidelines for midwifery-led care in labour. Nutrition in labour. 2012 [cited 2017 May 15]. Available from: https://www. rcm.org.uk/sites/default/files/Nutrition\%20 in\%2oLabour.pdf.

7. Maganha e Melo CR, Peraçoli JC. Measuring the energy spent by parturient women in fasting and in ingesting caloric replacement (honey). Rev Lat Am Enfermagem. 2007;15(4):612-7.
8. Giugliano D, Ceriello A, Esposito K. Glucose metabolism and hyperglycemia. Am J Clin Nutr. 2008;87(1):217S-22.

9. American College of Nurse-Midwives. Providing oral nutrition to women in labor. $\mathrm{J}$ Midwifery Womens Health. 2016;61(4):52834.

10. Malin GL, Bugg GJ, Thornton J, Taylor MA, Grauwen N, Devlieger R, et al. Does oral carbohydrate supplementation improve labour outcome? A systematic review and individual patient data meta-analysis. BJOG. 2016;123(4):510-7.

11. Kong F, Singh RP. Disintegration of solid foods in human stomach. $\mathrm{J}$ Food Sci. 2008;73(5):R67-80.

12. Rahmani R, Khakbazan Z, Yavari $P$, Granmayeh M, Yavari L. Effect of oral carbohydrate intake on labor progress: a randomized controlled trial. Iran J Public Health. 2012;41(11):59-66.

13. Khanna GL, Manna I. Supplementary effect of carbohydrate-electrolyte drink on sports performance, lactate removal \& cardiovascular response of athletes. Indian $\mathrm{J}$ Med Res. 2005;121(5):665-9.

14. de Souza P, do Nascimento Simões A, Puiatti M, Junior JG, da Silva Vieira M. Carbohydrate metabolism and quality of fruits from the Cucumis genus. Acad J Agric Res. 2013;1(7):101-5.

15. Thompson DL. Fitness focus copy-and-share: carbohydrate loading. ACSMs Health Fit J. 2008;12(2):5.

16. Asif HM, Akram M, Saeed T, Khan MI, Akhtar N, ur Rehman R, et al. Carbohydrates. IRJBB. 2011;1(1):1-5.

17. Jeukendrup A. Carbohydrate supplementation during exercise: does it help? How much is too much. Sports Sci Exchange. 2007;20(3):106.

18. Wiberg-Itzel E. Lactate level in amniotic fluid, a new diagnostic tool. In: Sifakis S, Vrachnis N, editors. From preconception to postpartum. Rijeka, Croatia: INTECH; 2012. p. 221-42.

19. Kato M, Kurakane S, Nishina A, Park J, Chang $\mathrm{H}$. The blood lactate increase in high intensity exercise is depressed by Acanthopanax sieboldianus. Nutrients. 2013;5(10):413444. 